\title{
NUTRIENT CONTENT, PROTEIN DIGESTIBILITY, AND ACCEPTABILITY OF SUBSTITUTING TEMPEH GEMBUS NUGGETS WITH TILAPIA FISH
}

\author{
Ina Susanti ${ }^{1}$, Diana Nur Afifah ${ }^{1,2 *}$, Hartanti Sandi Wijayanti ${ }^{1,2}$, Ninik Rustanti ${ }^{1,2}$ \\ ${ }^{1}$ Department of Nutrition Science, Faculty of Medicine, Universitas Diponegoro, Jl. Prof. H. Soedarto, SH, Tembalang, \\ Semarang 1269, Indonesia \\ ${ }^{2}$ Center of Nutrition Research (CENURE) Jl. Prof. H. Soedarto, SH, Tembalang, Semarang 1269, Indonesia \\ *Email: diananurafifah@live.undip.ac.id; ${ }^{1}$ Ailiationty E-mail: jurnal@gmail.com
}

\begin{abstract}
Nuggets are protein rich food that is widely; consumed in Indonesia because of its good taste and easy preparation. The substitution of tilapia fish in tempeh gembus nugget act as a healthy alternative composition which contain high protein, fiber, but low in fat. Therefore, this research was aimed to determine the effect of substitution of tilapia fish on the nutrient content, protein digestibility, and acceptability of tempeh gembus nuggets to obtain a formulation in accordance with the Daily Value (DV) $2150 \mathrm{kcal}$. A randomized experimental study was carried out on tilapia fish in substitution of $0 \%, 20 \%, 40 \%, 80 \%$, and $100 \%$. The protein, fat, carbohydrate, water, ash, and dietary fiber content analysis were determined using the Kjeldahl, Soxhlet, carbohydrate difference, gravimetric, dry ash, and enzymaticgravimetric methods. Furthermore, the protein digestibility was conducted by in vitro method, while the organoleptic tests were determined using hedonic tests. The organoleptic data was statistically analysed using ANOVA and Friedman tests. The substitution of tilapia fish increased the content of protein, water, and dietary fiber while decreasing fat, carbohydrates, ash, and protein digestibility. The most preferred tempeh gembus nugget formulation by panelists was $80 \%$ substitution treatment of tilapia fish. In conclusion, the recommended formulations are the substitution of $40 \%$ and $80 \%$ of tilapia fish considering the nutrient content, protein digestibility and acceptability.
\end{abstract}

Keywords: Tempeh gembus, Tilapia fish, Nuggets, Nutrient content, Protein digestibility

\section{INTRODUCTION}

The persistent increase of overweight and central obesity in developing countries such as Indonesia is a serious public health issue increased by $7 \%$ compared to the $14.8 \%$ recorded in 2013 . The prevalence of overweight and central obesity in adults have increased from $11.5 \%$ and $26.6 \%$ in 2013 to $13.6 \%$ and $31 \%$ in 2018 (Balitbang Kemenkes RI, 2018).

Obesity occurs due to a particular imbalance lifestyle especially with physical inactivity and imbalance nutrient intakes. Globalization and industrialization have greatly affected fast food development, which is generally considered to have a low nutritional value due to its high fatty, salt, and low fiber content (Dirjen Bina Gizi KIA, 2011). Burhan et al. (2012) research showed that consumption pattern of fatty food sources increases the central obesity risk by 9.3 times. Some studies conducted in America from 2003 to 2006 showed that low fiber consumption was also associated with the risk of obesity (Brauchla et al., 2012).
In Indonesia, the consumption of fast food, particularly nuggets, gradually becomes a habit in the community because it is easily obtained and can be served quickly. Besides, increasing public awareness of nutrition and health encourages people to practice healthy living (Suwoyo, 2006).

In Indonesia, chicken nuggets are generally consumed by the citizens. They enjoy its taste, irrespective of its high protein content (Laksono et al., 2012). Previous studies by Febrisiantosa et al. (2012) stated that it has high fat and cholesterol content, however, it comprises low fiber. Kurnia et al. (2019) reported that $100 \mathrm{~g}$ of chicken nuggets has an energy content of $335.54 \mathrm{kcal}$, which comprises of $20.72 \mathrm{~g}$ carbohydrate, 9.30 g protein, and $23.94 \mathrm{~g}$ fat. Despite its popularity, several research tried to create healthier nuggets by reducing the high fat content (Brunner, 2016; Petracci et al., 2013).

Tempeh gembus is made from tofu pulp, which has protein, low fat, and high fiber contents. A hundred gram of tempeh gembus has an energy content of $65.10 \mathrm{kcal}$, which consisted of 3.41 
g protein, $0.20 \mathrm{~g}$ fat, $11.94 \mathrm{~g}$ carbohydrate, and $3.93 \mathrm{~g}$ fiber (Sulchan and Nur, 2007). Tofu pulp is usually fermented by microorganisms, and it is also used in making soybean tempeh. Tempeh gembus possess special health effects such as antiinflammation, antimicrobial, and some important nutrient content due to its fermentation process (Noviana et al., 2018, Afifah et al., 2014a, 2014b, 2017, 2018; Kurniasar et al., 2017; Damanik et al., 2018).

As an alternative of substituting chicken as animal protein, tilapia fish can be used. Therefore, tilapia fish is added to tempeh gembus nuggets to boost its nutritional value because it has limited amino acids, namely Methionine. It was further reported that $100 \mathrm{~g}$ of tempe gembus, consisted of $50 \mathrm{mg} / 100 \mathrm{~g}$ of Methionine (Damanik et al., 2018). Subsequently, the higher the essential amino acid contents from food, the more effective the protein. Permatasari (2012) stated that $100 \mathrm{~g}$ of tilapia fish contains approximately $553 \mathrm{mg} / 100$ $\mathrm{g}$ of methionine while its nutritional content is $89 \mathrm{kcal}$, which included $18.7 \mathrm{~g}$ protein, $1 \mathrm{~g}$ fat, 0 $\mathrm{g}$ carbohydrate, $52 \mathrm{mg}$ cholesterol, and $0 \mathrm{~g}$ fiber (Mien et al., 2009). The previous study observed that nutrient content of fresh tilapia fish $(80 \%$ minced tilapia fish) had $14.72 \%$ protein, $4.21 \%$ fat, $1.64 \%$ ash content and acceptable flavor, aroma, and overall sensory qualities with a score more than five (Jayasinghe et al., 2013).

Ertanto et al. (2008) reported that the protein nutritional value of any food is determined by its content and digestibility, which is defined as its absorption effectiveness by body. Processing foods rich in protein reduces its nutritional value (Palupi et al., 2007). Therefore, the digestibility of any food product needs to be known.

The protein content of tempeh gembus and tilapia fish is expected to boost its intake, likewise its fiber content. The shelf life of tempeh gembus and tilapia fish is improved by processing them into a nugget. This study aims to examine the effect of substituting tilapia fish due to its nutritional content, protein digestibility, and acceptability of tempeh gembus nuggets.

\section{METHODS}

Study design used an experimental research with a random design based on one factor in the
Table 1. Formulation of tempeh gembus nuggets with substitution of tilapia fish

\begin{tabular}{lccccc}
\hline \multicolumn{1}{c}{ Ingredients } & $\mathbf{N 1}$ & $\mathbf{N 1}$ & $\mathbf{N 3}$ & $\mathbf{N 4}$ & $\mathbf{N 5}$ \\
\hline Tempeh gembus & $100 \%$ & $80 \%$ & $60 \%$ & $20 \%$ & $0 \%$ \\
Tilapia Fish & $0 \%$ & $20 \%$ & $40 \%$ & $80 \%$ & $100 \%$ \\
Total & $100 \%$ & $100 \%$ & $100 \%$ & $100 \%$ & $100 \%$ \\
\hline
\end{tabular}

form of variations in tilapia fish substitution. Replications given 4 times, thereby resulting in a total of 20 samples and 5 treatments. The nugget formulation is shown in Table 1.

Protein analysis was carried out at Nutrient Analysis Laboratory at University of Muhammadiyah Semarang, while the test of fat and water content was conducted at Diponegoro University Integrated Laboratory. In addition, analysis of ash content was carried out at Mutation and Feed Laboratory, Faculty of Animal and Agricultural Sciences at Diponegoro University, while dietary fiber and protein digestibility was carried out at CV. Che-mix Pratama Laboratory. This study was held from November 2017 to February 2018.

Tempeh gembus and tilapia fish were obtained from Jati market, Banyumanik village, Semarang. The processing of tempeh gembus nuggets with Tilapia fish is shown in Figure 1.

The analysis of protein, fat, water, ash, carbohydrate, dietary fiber contents, and protein digestibility were carried out by Kjeldahl (Magomya, 2014), Soxhlet (Zarnowski, 2004),

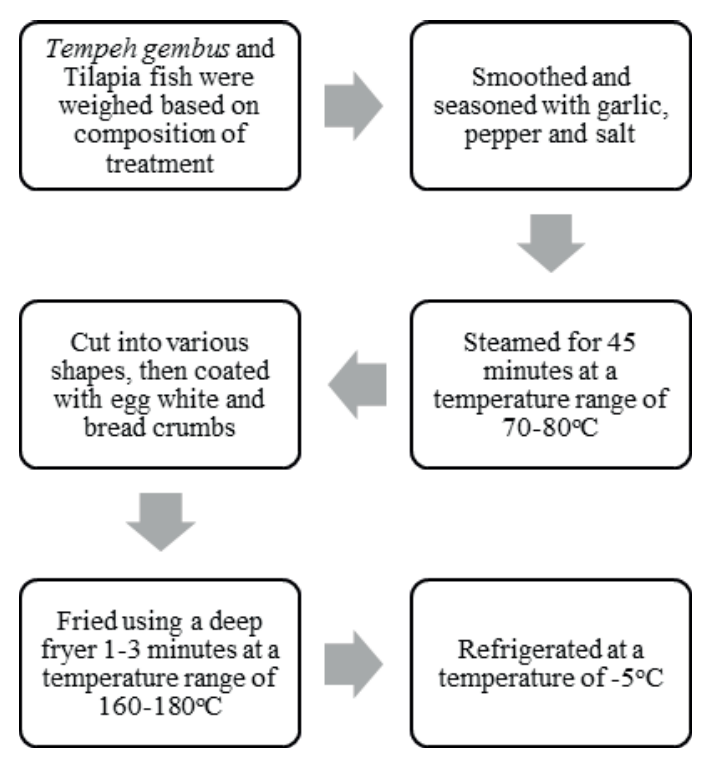

Figure 1. Flowchart for Nugget Processing. 
gravimetric, dry fogging, carbohydrate by different methods namely enzymatic-gravimetric (Gordon, 2002), and in vitro methods (Christine, 2012)

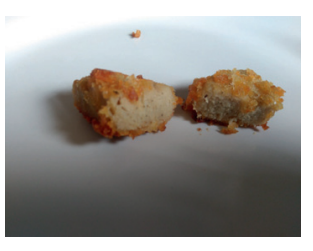

N1

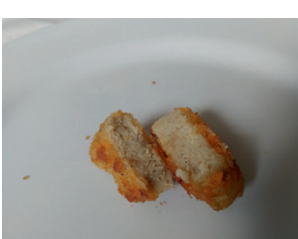

N3

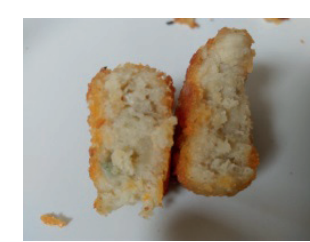

N5

Figure 2. Appearance of Nuggets with Different Formulations respectively. The appearance of tempeh gembus nuggets with Tilapia fish is shown in Figure 2 below.

Organoleptic and hedonic testing of tempeh gembus and tilapia fish which involves the taste, aroma, texture, and color was carried out by semitrained panelists, consisting of 20 students from Department of Nutrition, Diponegoro University. The results from hedonic test are categorized into a scale of 1 to 4 , namely $1=$ totally dislike, $2=$ dislike, $3=$ like, $4=$ really like. Assuming the average value obtained is below 1.51 it is included in "totally dislike" category, between 1.51 to 2.5 is in "dislike," 2.51-3.49 included in "like", and $>$ 3.49 included in "really like" categories (Aulia et al, 2017).

Data analysis is carried out using IBM (2009) SPSS application, while normality test was conducted by applying Shapiro-Wilk. The results from nutrients and protein digestibility testing were processed by applying One Way ANOVA test. Post-hoc Befferoni test was carried out, assuming the sample variations were similar while Gomes Howel technique was applied to dissimilar ones to

Table 2. Average Protein, Fat, Carbohydrate and Water Content of Nuggets per $100 \mathrm{~g}(\% \mathrm{w} . \mathrm{b})$

\begin{tabular}{lccccccc}
\hline \multirow{2}{*}{ Treatment } & \multicolumn{7}{c}{ Mean \pm SD } \\
\cline { 2 - 8 } & $\begin{array}{c}\text { Protein } \\
(\%)\end{array}$ & $\begin{array}{c}\text { Fat } \\
\mathbf{( \% )}\end{array}$ & $\begin{array}{c}\text { Carbohy- } \\
\text { drate (\%) }\end{array}$ & $\begin{array}{c}\text { Water } \\
\mathbf{( \% )}\end{array}$ & $\begin{array}{c}\text { Ash } \\
\mathbf{( \% )}\end{array}$ & $\begin{array}{c}\text { Dietary } \\
\text { Fiber (\%) }\end{array}$ & $\begin{array}{c}\text { Protein } \\
\text { Digestibility (\%) }\end{array}$ \\
\hline N1 & $6.66 \pm 0.22^{\mathrm{e}}$ & $12.94 \pm 0.55^{\mathrm{a}}$ & $18.10 \pm 2.64^{\mathrm{ab}}$ & $42.39 \pm 3.14^{\mathrm{abc}}$ & $4.68 \pm 0.21^{\mathrm{a}}$ & $15.29 \pm 0.40^{\mathrm{b}}$ & $93.50 \pm 0.94^{\mathrm{a}}$ \\
$\mathrm{N} 2$ & $8.48 \pm 0.15^{\mathrm{d}}$ & $11.93 \pm 0.47^{\mathrm{b}}$ & $13.04 \pm 0.84^{\mathrm{a}}$ & $46.93 \pm 0.49^{\mathrm{c}}$ & $3.35 \pm 0.51^{\mathrm{b}}$ & $16.26 \pm 0.20^{\mathrm{b}}$ & $92.69 \pm 3.05^{\mathrm{b}}$ \\
N3 & $9.71 \pm 0.25^{\mathrm{c}}$ & $10.83 \pm 0.17^{\mathrm{c}}$ & $12.85 \pm 0.87^{\mathrm{a}}$ & $46.31 \pm 0.52^{\mathrm{c}}$ & $2.54 \pm 0.99^{\mathrm{abc}}$ & $17.76 \pm 0.40^{\mathrm{a}}$ & $86.23 \pm 0.63^{\mathrm{c}}$ \\
N4 & $13.53 \pm 0.44^{\mathrm{ab}}$ & $9.85 \pm 0.95^{\mathrm{d}}$ & $7.85 \pm 0.71^{\mathrm{b}}$ & $48.91 \pm 0.32^{\mathrm{b}}$ & $1.87 \pm 0.08^{\mathrm{c}}$ & $18.00 \pm 0.40^{\mathrm{a}}$ & $86.61 \pm 0.63^{\mathrm{de}}$ \\
N5 & $13.69 \pm 0.24^{\mathrm{ab}}$ & $8.02 \pm 0.18^{\mathrm{e}}$ & $7.38 \pm 0.69^{\mathrm{b}}$ & $50.54 \pm 0.43^{\mathrm{a}}$ & $1.61 \pm 0.44^{\mathrm{c}}$ & $18.75 \pm 0.58^{\mathrm{a}}$ & $84.88 \pm 0.84^{\mathrm{de}}$ \\
p value $^{1}$ & $\mathrm{p}<0.001$ & $\mathrm{p}<0.001$ & $\mathrm{p}<0.001$ & $\mathrm{p}<0.001$ & $\mathrm{p}<0.001$ & $\mathrm{p}<0.001$ & $\mathrm{p}<0.001$ \\
\hline
\end{tabular}

Note: Numbers followed by different superscript letters (a, b, c, d, e) show a significantly distinct difference in ${ }^{1}$ One Way ANOVA test.

Table 3. Nutritional Content of Nuggets per $100 \mathrm{~g}(\% \mathrm{~d} . \mathrm{b})$

\begin{tabular}{lccccc}
\hline & & & Mean \pm SD & \\
Treatment & Protein (\%) & Fat (\%) & Carbohydrate (\%) & Ash (\%) & Dietary Fiber (\%) \\
\cline { 2 - 6 } & $11.47 \pm 0.24^{\mathrm{a}}$ & $22.51 \pm 1.27^{\mathrm{abc}}$ & $31.31 \pm 2.97^{\mathrm{a}}$ & $8.02 \pm 0.77^{\mathrm{a}}$ & $26.67 \pm 0.68^{\mathrm{a}}$ \\
N1 & $15.99 \pm 0.31^{\mathrm{b}}$ & $22.48 \pm 0.14^{\mathrm{a}}$ & $24.56 \pm 1.45^{\mathrm{b}}$ & $6.31 \pm 0.95^{\mathrm{a}}$ & $30.64 \pm 0.70^{\mathrm{b}}$ \\
N2 & $18.08 \pm 0.51^{\mathrm{c}}$ & $20.18 \pm 0.46^{\mathrm{b}}$ & $23.92 \pm 1.44^{\mathrm{b}}$ & $4.74 \pm 1.87 \mathrm{a}^{\mathrm{b}}$ & $33.07 \pm 0.80^{\mathrm{c}}$ \\
N3 & $26.48 \pm 1.03^{\mathrm{de}}$ & $19.28 \pm 0.27^{\mathrm{bc}}$ & $15.36 \pm 1.29^{\mathrm{c}}$ & $3.64 \pm 0.14^{\mathrm{b}}$ & $35.22 \pm 0.21^{\mathrm{d}}$ \\
N4 & $27.70 \pm 0.63^{\mathrm{de}}$ & $16.21 \pm 0.34^{\mathrm{d}}$ & $14.92 \pm 1.34^{\mathrm{c}}$ & $3.25 \pm 0.90^{\mathrm{b}}$ & $37.91 \pm 1.06^{\mathrm{e}}$ \\
N5 & $\mathrm{p}<0.001$ & $\mathrm{p}<0.001$ & $\mathrm{p}<0.001$ & $\mathrm{p}<0.001$ & $\mathrm{p}<0.001$ \\
\hline
\end{tabular}

Note: Numbers followed by different superscript letters (a, b, c, d, e) show significant differences in ${ }^{1}$ One Way ANOVA Test 
determine significancy effect between treatments. Organoleptic, Friedman, and Wilcoxon tests were simultaneously applied to determine significancy effect of tempeh gembus and tilapia fish (Field, 2017).

\section{RESULTS AND DISCUSSIONS}

Based on the analysis results, a certain disparity was detected between the nutritional content of tilapia fish and the digestibility of protein in nuggets. It was further discovered that the protein, water, and dietary fiber contents in nuggets increased in accordance with the proportion of tilapia fish. Otherwise, there was decrease in fat, carbohydrate, and ash contents, as well as the digestibility of protein with an increasing proportion of tilapia fish.

\section{Protein Content}

The protein content of tempe gembus was $3.41 \%$ compared to the $18.7 \%$ contained in tilapia fish (Mien et al., 2009). The highest protein content is in the substitution of $100 \%$ tilapia fish in the nuggets. Based on BSN (2014), the quality requirements for nuggets are at least a $9 \%$ wet basis, as well as tempeh gembus nuggets with $40 \%$, $80 \%$, and $100 \%$ of tilapia fish substitution which met the quality requirements of chicken. Based on statistical tests, there was a significant effect ( $p<0.001$ ) of tilapia substitution on the increasing protein content of nuggets. Tilapia fish has a higher protein content than tempeh gembus. Therefore its substitution in the nuggets increases its nutritional value.

The consumption of $50 \mathrm{~g}$ of nuggets, which is equivalent to 2 pieces is consumed in a meal. It produces a Daily Value (DV) of $2150 \mathrm{kcal}$, while $40 \%, 80 \%$ and $100 \%$ substitution of tilapia fish fulfill the protein requirements of $8.90 \%, 11.27 \%$, $11.40 \%$ respectively. Protein functions as the building block of tissues, it produces antibodies that protect the body from illnesses and infections and also serves as a source of fuel (Winarno, 2008). According to several studies, high-protein diets reduce weight significantly (Noakes et al., 2005; Clifton et al., 2008).

\section{Fat Content}

The lowest fat content was discovered in the nugget treatment with $100 \%$ tilapia fish substitution, while the highest was detected in the treatment with $0 \%$ tilapia fish. Based on the quality requirements, the maximum fat content of nuggets is $20 \%$ by wet basis (BSN, 2014). It was therefore ensured that none of the treatments exceed that value. In accordance with the statistical tests, tilapia fish substitution had $(\mathrm{p}<0.001)$ effect on fat contents, which was influenced by frying method. During this process, the water in the nuggets evaporates while the oil fills the empty pores, it previously occupied (Ketaran, 2005). The amount of oil absorbed at the center is equivalent to the amount of water that evaporates. Ratu (2009), reported that the thicker the nugget layer, the more oil is absorbed (Ratu, 2009).

The treatment, which involves the substitution of $100 \%$ tempeh gembus tends to have a highfat content compared to the others, due to the absorption of oil. This is in accordance with a study that compared the absorption of oil in various concentrations of soybean pulp with tapioca flour. The highest fat content was discovered in the treatment with the highest soybean pulp (Yustiana, 2011). Furthermore, tempeh gembus and tilapia fish both contain unsaturated fatty acids. Sulchan (2007) reported that tempeh gembus contain essential fatty acids, namely linoleic, linolenic, and oleic acids. The dominant fatty acids found in tilapia fish are omega- 3 fatty acids, particularly EPA (Eicosapentanoic Acid) and DHA (Docosahexanoic Acid) (Partina et al., 2015). These fatty acids have important roles such as maintaining cell membranes, regulating cholesterol metabolism, reducing blood pressure, reducing the risk of coronary heart diseases, inhibiting hepatic lipogenesis, lipid transporting, anti-inflammation, and developing brain tissue and nervous system (Mayes, 2003). Assuming $50 \mathrm{~g}$ of nuggets, which is equivalent to 2 pieces is consumed in a meal, it produces a DV of $2150 \mathrm{kcal}$, while $40 \%, 80 \%$, and $100 \%$ of tilapia fish substitution fulfill the fat requirements of $8.80 \%, 7.35 \%$, and $5.98 \%$ respectively. 


\section{Carbohydrate Content}

The carbohydrate content of nugget decreases with increasing substitution of tilapia fish. According to the carbohydrate by different method, it is strongly influenced by other nutrients. In addition, its content in the tempeh gembus is greater, approximately $11.94 \%$ compared to tilapia fish, which is $0 \%$. Based on the results from statistical tests, an effect ( $p<0.001$ ) of tilapia fish substitution tends to decrease carbohydrate nugget content. All nugget treatments met the quality requirements, a maximum of $25 \%$ wet weight (BSN, 2014). This research showed that carbohydrate content ranges from $7.38-18.10 \%$. The least was discovered in the $100 \%$ tilapia fish substitution, while the highest was the $0 \%$ tilapia fish. Assuming $50 \mathrm{~g}$ of nuggets which is equivalent to 2 pieces is consumed in a meal, a DV (Daily Value) of $2150 \mathrm{kcal}$ is generated, while $40 \%, 80 \%$ and $100 \%$ of tilapia fish substitution treatment satisfied the carbohydrate requirements of $3.47 \%$, $1.20 \%$, and $1.13 \%$ respectively.

\section{Water Content}

The water content of the nugget increased by increasing the substitution of tilapia fish. The lowest water content was found in $0 \%$ tilapia fish substitution, which was determined to be $40.24 \%$. While the highest was discovered in substitution of $100 \%$ tilapia fish, which was equivalent to $50.54 \%$. All treatments met the nugget's quality requirements, which is a maximum of $60 \%$ wet basis (BSN, 2014). The water content of fresh tempeh gembus was $81.90 \%$, and fresh tilapia fish was $79.70 \%$ (Mien et al., 2009). Based on the results from statistical test, there was a significant effect $(p<0.001)$ on the increased water content. This is because tilapia fish has a higher nutritional content than tempeh gembus. Temperature of steaming process created a bond between components, such as carbohydrates, fats, and proteins, in order for water to bind to the material, thereby leading to a rise in the proportion of tilapia fish (Sulthoniyah et al., 2013).

On the other hand, frying reduced the water content because the process led to its evaporation, while the pores were replaced by oil (Ketaran, 2005). Generally, the water content decreases after cooking process. Winarno (2008) reported that processing food with high temperatures causes evaporation of the product water content. In addition, the increase in temperature causes an increase in the evaporation of water molecules from the surface. The Increase in tilapia fish substitutes reduces duration of fry and evaporation. The treatment process causes water in material less than before processed. According to a certain study, transfer of heat and movement of water flow causes evaporation and drying of food nutrients. This evaporation decreases the water content and resulted in dehydration processes such as decreasing the concentration of protein and fat in the food (Morris et al., 2004).

\section{Ash Content}

Based on the results from the statistical test, there was a significant effect $(p<0.001)$ on the ash content decrease. Ash content in both fresh tempeh gembus and tilapia fish was 1.1\% (Mien et al., 2009). Ash is the residual substance from the combustion of organic material. The purpose of determining the ash content is to detect whether the processes are effective or not, despite being aware of the type of material used. It also serves as a useful parameter to ascertain nutritional value of food ingredients. Higher ash content implied that the quality of food was poor (Sudarmadji et al., 2007). In addition, its determination is closely related to mineral content of a material, purity, and cleanliness of the substance produced. High ash content means that the food is contaminated by various substances such as sand, etc. (Park and Bell, 2004).

The ash content of nugget was decreasing while increasing the proportion of tilapia fish due to the water-soluble minerals found in tempeh gembus. However, it was slightly evaporated compared to water-soluble minerals in tilapia fish. The ash content of food and its composition depended on the type of material and the way it burnt, the different types of organisms, as well as the environment of organism (Puwastien et al., 2011). The value of ash content in fried foods depend on duration and temperature of frying pan. An increase in temperature caused a decrease in water content as well as the evaporation of the more water-soluble minerals (Sumiati, 2008). 


\section{Dietary Fiber Content}

An increase in dietary fiber caused an increase in the substitution of tilapia fish. Based on the results from statistical tests, there was a significant effect ( $p<0.001)$ of dietary fiber content, which was due to increase in the amount of amino acid. Treatment of $100 \%$ tilapia fish substitution resulted on excessive amino acids compared to other treatments. They were bound to the sugars derived reduction from cornstarch and were added to 15 $\mathrm{g}$ of each treatment. These amino acids causes Maillard reactions, thereby producing melanoidin compounds that are indigested by amylase enzyme in dietary fiber analysis to be referred to as insoluble (Thed et al., 1995; Baston et al., 2014). In addition, the fermentation process in tempeh gembus also reduced fiber content. Therefore an increase in its proportion caused a decrease in fiber content (Darmawan, 2006). According to The Food and Drug Administration, the recommended Daily Value (DV) of $2150 \mathrm{kcal}$. The $40 \%, 80 \%$, and $100 \%$ of tilapia fish substitution met the fiber requirements of $29.6 \%, 30 \%$, and $31.25 \%$ respectively when $50 \mathrm{~g}$ of nuggets which was equivalent to 2 pieces were consumed in one meal. Fiber intake plays a role in regulating body weight relating to waist circumference, as well as affected the distribution of body fat caused by insulin expression (Uttara et al., 2011). In addition, it increases satiety compared to complex carbohydrates and simple sugars, and several studies have reported its success in regulating body weight (Ventura et al., 2008; Carlos et al., 2011).

\section{Protein Digestibility}

The digestibility of proteins in nuggets decreased with increasing substitution of tilapia. Nugget with higher proportion of tempeh gembus, had higher digestibility of protein. This result was in accordance with previous research by Arini et al. (2019) that showed the difference of protein digestibility of meatballs between tempeh gembus addition $(\mathrm{p}<0.001)$. It was caused by fermentation process of tempeh gembus, which increased protein digestibility, microbes hydrolysis of complex proteins into simpler amino acids or peptides in the presence of proteolytic enzymes (Onweluzo et al., 2009). Conversely, an increase in microbial biomass during fermentation process in accordance with secretion of several extracellular enzymes (soluble proteins) in single cells caused an increase in the protein content (Oboh et al., 2007).

Other factors that increased digestibility of protein are heating process causing protein denaturation, which was opening three-dimensional arrangement of protein molecules into a random structure. This facilitated pepsin enzyme to break down phenylalanine, tyrosine, and tryptophan residues thereby increasing digestibility (Asrulloh, 2012; Cueves-Rodriguez et al., 2006). The frying stage in this research made protein content in nugget became denatured. Denaturation is process of breaking bonds in molecules of protein that will tend to be easily digested by digestive enzymes (Saputra, 2014). Protein digestibility decreased when a Maillard reaction occurred during heating, leading to an increase in temperature (Meilgaard et al., 2006). This happens due to prevention of enzymes into substrate (protein) or the closure of the side of protein that tends to be attacked by cross-linked enzymes formed by amino acids produced in Maillard reaction. Besides, application of $180-300^{\circ} \mathrm{C}$ temperature reduced protein digestibility due to racemization, thereby having different flavors (Puwastien et al., 2011).

\section{Acceptibility Acceptibility}

Table 4 showed the results from analysis based on taste, aroma, texture, and color. In accordance with the results from analysis, a difference in substitution of tilapia fish was discovered based on its taste, aroma, and texture. However, it had the same color. In terms of taste, aroma, texture, and color, all treatments were accepted or preferred by panelists. Consequently, its taste, aroma, and texture tended to be immensely preferred as the proportion of tilapia fish increases in treatment of nuggets. The organoleptic test results showed that nuggets with $80 \%$ substitution treatment and $100 \%$ tilapia were most preferred by the panelists.

Food is recognized and distinguished by its salty, sweet, sour, and bitter taste caused by the materials dissolved in the mouth (Meilgaard et al., 2006). The flavor was one of the organoleptic aspects that greatly affect panelist preference and their decision to either reject or accept a product (Nadimin et al., 2012). The results from statistical test showed a significant effect on the 
taste of nuggets $(\mathrm{p}=0.001)$. An average of all flavors of tempeh gembus nuggets with tilapia fish substitutes, were accepted by panelists. The most preferred were nuggets treatment of $80 \%$ tilapia fish substitution. The flavor of tempeh gembus was less preferred because of its bitter taste; however the addition of spices improved its taste. In addition, frying also added savory flavor to food ingredients (Winarno, 2008). Tilapia fish were preferred because of its distinctive taste. A certain study reported that its amino acid affected the taste of food. Therefore, the adequate concentration of amino acids significantly increased the taste of food products (Wong et al., 2008).

Aroma is a distinctive smell that was subjective and difficult to measure because everyone had different sensitivity and preferences (Van Boekel, 2006). It is one of the determinants of a food product quality. Winarno (2008) reported that aroma emerges from water-soluble flavors and volatile fat (evaporating). All aroma in nugget treatment were generally acceptable. The results from statistical test showed a significant effect on nugget aroma $(\mathrm{p}=0.016)$. The highest aroma score was in nugget treatment of $80 \%$ tilapia fish substitution while the lowest score was 2.65 in the treatment of $0 \%$ substitution, due to strong unpleasant smell of tempeh gembus. Aroma was caused by the role of lipoxygenase enzyme in soybean seeds. The enzyme reacted with fat and produced organic compounds calledethyl-phenylketone (Megia et al., 2010).

All textures of nugget treatment were adequately accepted. Results from statistical test showed a significant effect on nugget texture ( $p$ $=0.006$ ). The highest texture score was found in nugget treatment of $100 \%$ tilapia fish substitution, which was 3.15 , while the lowest score was in treatment with $0 \%$ tilapia with a score of 2.65 .

Heating process affected the texture of nugget, either during steaming or frying. The steaming process inhibited the deterioration of fish quality (Jacoeb et al., 2013). Textures formed during cooking process are due to the properties of protein gelation and Maillard reactions. Proteins form gels by forming cross-linked polymers through covalent or non-covalent bonds formed tissues capable of capturing water (Agustini et al., 2015). Maillard reactions occurred during frying process of nugget, and it affected the texture due to crosslinked protein as well as the formation of both soluble and insoluble high molecular weight compounds. The formation of protein cross-linking occurred in the final Maillard reaction means that an increase in duration of steaming caused an increase in accumulated cross-linking proteins, thereby affecting texture (Gerrad, 2002).

Color is the first indicator assessed in acceptance test. Panelists provided the fastest and easiest response due to the color of food product. Unattractive Food colors reduced the reception of panelists irrespective of the fact that nutritional content was complete (Gerrad, 2002). According to the results from statistical test, the tilapia fish showed no effect $(p=0.055)$ on the nugget color. In addition, It was influenced by certain characteristics such as bright color of tempeh gembus and the flesh of white tilapia fish, which dominated nuggets color.

The surface of the nugget was brownish due to frying, thereby resulting in Maillard reaction, such as non-enzymatic browning reaction between sugars reduction and groups free of amino acids. The end product was an active polymerized

Table 4. The Results from the Test's Analysis for the Acceptability of Tempeh Gembus Nuggets through the Substitution of Tilapia Fish

\begin{tabular}{llccccccc}
\hline \multirow{2}{*}{ Treatment } & \multicolumn{2}{c}{ Taste } & \multicolumn{2}{c}{ Aroma } & \multicolumn{2}{c}{ Texture } & \multicolumn{2}{c}{ Color } \\
\cline { 2 - 9 } & Mean \pm SD & Category & Mean \pm SD & Category & Mean \pm SD & Category & Mean \pm SD & Category \\
\hline N1 & $2.75 \pm 0.64^{\mathrm{a}}$ & Like & $2.65 \pm 0.67^{\mathrm{a}}$ & Like & $2.65 \pm 0.67^{\mathrm{a}}$ & Like & $2.85 \pm 0.59$ & Like \\
$\mathrm{N} 2$ & $2.65 \pm 0.49^{\mathrm{ab}}$ & Like & $3.05 \pm 0.39^{\mathrm{b}}$ & Like & $2.95 \pm 0.39^{\mathrm{ab}}$ & Like & $3.15 \pm 0.37$ & Like \\
N3 & $2.85 \pm 0.49^{\mathrm{ab}}$ & Like & $2.90 \pm 0.55^{\mathrm{ab}}$ & Like & $2.95 \pm 0.39^{\mathrm{ab}}$ & Like & $3.00 \pm 0.32$ & Like \\
N4 & $3.25 \pm 0.55^{\mathrm{c}}$ & Like & $3.15 \pm 0.49^{\mathrm{b}}$ & Like & $3.10 \pm 0.55^{\mathrm{ab}}$ & Like & $2.80 \pm 0.69$ & Like \\
N5 & $3.25 \pm 0.64^{\mathrm{ac}}$ & Like & $3.05 \pm 0.60^{\mathrm{ab}}$ & Like & $3.15 \pm 0.59^{\mathrm{b}}$ & Like & $3.15 \pm 0.59$ & Like \\
p value $^{1}$ & \multicolumn{2}{c}{$\mathrm{p}=0.001^{*}$} & \multicolumn{2}{c}{$\mathrm{p}=0.017^{*}$} & & $\mathrm{p}=0.006^{*}$ & & $\mathrm{p}=0.055$ \\
\hline
\end{tabular}

Description: Numbers followed by different superscript letters $(a, b, c)$ show a significant difference ${ }^{1}$ Friedman Test 
aldehyde with an amino group producing a brown compound referred to as melanoidin (Fellow, 2000).

\section{CONCLUSION}

Based on analysis of nutritional content and organoleptic tests, nuggets with $-40 \%, 80 \%$ and $100 \%$ of tilapia fish was found to be recommended substitution formulation. However, nuggets with $40 \%$ and $80 \%$ of tilapia fish was preferred because it has higher protein digestibility than $100 \%$ substitution treatment. Besides, it also fulfills all quality requirements of nuggets.

\section{ACKNOWLEDGEMENT}

The author delivers great gratitude to Institute for Research and Community Service (LPPM), Universitas Diponegoro for funding this research.

\section{REFERENCES}

[BSN] National Standardization Agency of Indonesia. (2014). Syarat Mutu Nugget [Nugget Quality Requirements] SNI No. 6683:2014. Ministry of Industry Republic of Indonesia.

Afifah, D.N., Anjani, N.R., Syah, D., Yanti., \& Suhartono, M.T. (2017). Proteomics study of extracellular fibrinolytic proteases from Bacillus licheniformis $\mathrm{RO} 3$ and Bacillus pumilus 2.g isolated from In-donesian fermented food. IOP Conferences Series: Earth and Environmental Science, 55, 1-10. doi: 10.1088/17551315/55/1/012025.

Afifah, D.N., Nabilah. N., Supraba, G.T., Pratiwi, S.N., Nuryanto., \& Sulchan. M. (2018). The Effects of Tempeh Gembus, an Indonesian Fermented Food, on Lipid Profiles in Women with Hyperlipidemia. Current Nutrition \& Food Science, 14, 1-9. doi: 10.2174/1573401314666 180807112549.

Afifah, D.N., Sulchan, M., Syah, D., Yanti., \& Suhartono, M.T. (2014a). Isolation and identification of fibrinolytic protease-producing microorganisms from Red Oncom and Gembus, Indonesia fermented soybean cakes. The Malaysian Journal of Microbiology, 10(4), 273279. doi: $10.21161 / \mathrm{mjm} .61914$.
Afifah. D.N., Sulchan, M., Syah, D., Yanti., Suhartono, M.T., \& Kim. J.H. (2014b). Purification and characterization of a fibrinolytic enzyme from Bacillus pumilus 2.g isolated from gembus an Indonesian fermented food. Preventive Nutrition and Food Science, 19(3),213-9. doi: 10.3746/pnf.2014.19.3.213.

Agustini, S., Priyanto, G., Santoso, S., \& Pambayun, R. (2015). The influence of process modification on the sensories quality of kue delapan jam. Jurnal Dinamika Penelitian Industri, 26 (2), 107-115.

Arini, AMS., Afifah, DN., \& Dieny, FF. (2019). The effect of tempeh gembus substitution on protein content, calcium, protein digestibility and organoleptic quality of meatballs. Current Research in Nutrition and Food Science. 7(3), 828-841.

Asrullah. M,. (2012). Denaturation and Protein Digestibility in the Processing of Lawa Bale (Traditional Food of Suth Sulawesi). Media Gizi Masyarakat Indonesia, 1(2), 84-90.

Aulia, S.S., Rustanti, N., \& Fitranti, D.Y. (2017). Fortification of NaFeEDTA in orange fleshed sweet potato cookies as alternative product for iron deficiency anemia. Jurnal Gizi Pangan, 12(3): 161-168.

Balitbang Kemenkes RI. (2018). Riset Kesehatan Dasar (Riskesdas). Jakarta: Kementrian Kesehatan.

Baston, D.M., Monaro, E., Siguemoto, E., \& Sefora, M. (2014). Maillard Reaction Product in Processed Food: Pros and Cons. Brazil: Nutrition Department, School of Public Health.

Brauchla, M., Juan, W., Story, J., \& Kranz, S. (2012). Sources of dietary fiber and association of fiber intake with childhood obesity risk (in 12-18 years old) and diabetes risk of adolescent 12-18 years old: NHANES 2003-2006. Journal of Nutrition and Metabolism, 2012(3): 736258. 1-7. doi: 10.1155/2012/736258.

Brunner, T.A. (2016). Convenience Food. In Encyclopedia of Food and Health, $1^{\text {st }}$ ed., Elsevier, 312-315.

Burhan, Z.F., Sirajuddin, S., \& Indrisari, R. (2011). Consumption Pattern towards the Incidence of Central Obesity in Employee of Government in Bupati Office Jeneponto [Undergraduate Thesis]. Makassar: Universitas Hasanuddin Makassar. 
Carlos, J.J., Joey, C.E., Gregory, J.N., Karen, A., Ortiz., \& Paul, C.Y. (2011). Dietary Fiber and Nutrient Density Are Inversely Associted with the Metabolic Syndrome in US Adolescents. Journal of the American Dietetic Association, 111(11), 1688-1695.

Christine, A.B., John, A.M., \& Paul, J.M. (2012). In vitro determination of dietary protein and amino acid digestibility for humans. British Journal of Nutrition, 108 (S2),S282-S287. doi: 10.1017/ S0007114512002310

Clifton, P., Keogh, J., Noakes, M., \& Al, E. (2008). Long term effects of a high-protein weightloss diet. Journal of the American Dietetic Association, 87(1), 23-29. doi: 10.1093/ ajcn/87.1.23.

Cueves-Rodriguez, E.O., Verdugo-Montoya, N.M., Angulo-Bejarano, P.I., MillanCamilo, J., Mora-Escobedo, R., Bello-Pe'rez, LA., GarzonTiznado, J.A., \& Reyes-Moreno, C. (2006). Nutritional properties of tempeh flour from quality protein maize (Zea mays L). LWT- Food Science and Technology 39(10), 1072-1079. doi:10.1016/j.1wt.2005.07.003.

Damanik, R.N.S., Pratiwi, D.Y.W., Widyastuti, N., Rustanti, N., Anjani, G., \& Afifah, D.N. (2018). Nutritional Composition Changes during Tempeh Gembus Processing. IOP Conferences Series: Earth and Environmental Science, 116, 012026, 1-10. doi: 10.1088/17551315/116/1/012026.

Darmawan. (2006). Effect of Fermented Cassava on the appearance of Male Goats. Jurnal Ilmiah Ilmu-Ilmu Peternakan, 9(2), 115-122.

Dirjen Bina Gizi. (2011). National Strategy: Application of Food Consumption Patterns and Physical Activity to Prevent Non-Communcable Diseases. Ministry of Health Republic of Indonesia. Bina Gizi: Jakarta. doi: 10.1016/j. jada.2011.08.008.

Ertanto, T., Surya, Y.S., \& Catrien. (2008). Determination of In vitro Comma Protein Digestibility as a Food Diversification of Vegetable Protein Sources [Undergraduate Thesis]. Bogor: IPB University.

Febrisiantosa, A., Istiqomah, L., Sofyan, A., Damayanti, E., Herdian., Julendra, H., \& Angwar, M. (2012). Percentage of carcass, fat, and cholesterol content of chicken meat with the addition of feed additives containing lactic acid bacteria and Ganoderma lucidium flour. In: Proceeding of Workshop Nasional Unggas
Lokal dalam Industri Perunggasan Nasional. LIPI.

Fellow, P. (2000). Food Processing Technology Principle and Practice. Cambridge: Wood Publishing in Food Science and Technology.

Field, A.P. (2017). Discovering statistic using IBM SPSS Statistics $\left(5^{\text {th }} E d\right.$.). London: SAGE Publications.

Gerrard, J.A. (2002). Protein cross-linking in food: methods, consequences, applications. Trends in Food Science \& Technology, 13(12), 391-399. doi: 10.1016/S0924-2244(02)00257-1.

Gordon, D.T., \& Okuma, K. (2002). Determination of total dietary fiber in selected foods containing resistant maltodextrin by enzymatic-gravimetric method and liquid chromatography: collaborative study. J of AOAC International, 85(2), 435-443. doi: 10.1093/jaoac/85.2.435.

IBM. (2009). IBM completes acquisition of SPPS Inc. Retrieved from http://www-03.ibm.com/ press/us/en/pressrelease/28522.wss

Jacoeb, A.M., Nurjanah., \& Aninta, S. (2013). The content of fatty acids and cholesterol (Lutjanus bohar) after steaming. Jurnal Pengolahan Hasil Perikanan Indonesia, 16(2), 168-176.

Jayasinghe, C.V.L., Silva, S.S.G., \& Jayasinghe, J.M.J.K. (2013). Quality Improvement of Tilapia Fish Nuggets by Addition of Legume Flour as Extenders. Journal of Food and Agriculture, 6(1-2), 32-44.

Ketaran, S. (2005). Introduction of Technology and Food Fat. Jakarta: UI Press.

Kurnia, R.A., Prameswari, G.N., Susilo, M.T., Melinda, A., \& Nasiha, N.H. (2019). Comparing Macronutrient Compositions and Sensory Characteristics of Jackfruit Nugget Formulation and Commercially Available Chicken Nugget. Advances in Social Science, Education and Humanities Research, 362(ACPES 2019), 233236. doi: 10.2991/acpes-19.2019.53.

Kurniasari, R., Sulchan, M., Afifah, D.N., Anjani, G., \& Rustanti, N. (2017). Influence variation of tempe gembus (an Indonesian fermented food) on homocysteine and malondialdehyde of rats fed an atherogenic diet. Romanian Journal of Diabetes Nutrition and Metabolic Diseases, 24(3), 203-11. doi: 10.1515/rjdnmd2017-0026

Laksono, M.A., Bintoro, V.P., \& Mulyani, S. (2012). Water Holding Capacity, Water Content, and Protein Content of Chicken Nuggets 
Subtituted by White Oyster Mushrooms. Animal Agriculture Journal 1(1), 685-689.

Magomya, A.M., Kubmarawa, D., Ndahi, J.A., \& Yebpella, G.G. (2014). Determination of plant proteins via the kjeldahl method and amino acid analysis: a comparative study. International Journal of Science \& Technology Research 3(4), 68-72.

Mayes, P.A. (2003). Fatty acid biosynthesis. In: Murray RK, Granner DK, Mayes PA, Rodwell VW, editors. Jakarta: Biokimia.

Megia, E., Hayat, S., \& Asep, S. (2010). Study on the performance of active-bentonite charcoal adsorption on soymilk. Jurnal Sains dan Teknologi Kimia, 2(1), 135-149.

Meilgaard, M.C., Carr, B.T., \& Civille, G.V. (2006). Sensory Evaluation Technique, $4^{\text {th }}$ ed. Texas (US): CRC Press.

Mien, K.M., Hermana., \& Rozanna, R. (2009). Tabel Komposisi Pangan Indonesia (TKPI) [Indonesian Food Composition Tabel]. Jakarta: Elex Media Komputindo.

Morris, A., Barnett, A., \& Burrows, O.J. (2004). Effect of processing on nutrient content of foods. Cajanus, 37(3), 160-164.

Nadimin, N., Ayu, S., \& Rauf, S. (2012). Consumer Acceptance of Dodol Rich in Nutrients Content. Media Gizi Pangan 13(1), 30-35.

Noakes, M., Keogh, J.B., Foster, P.R., \& Clifton, P.M. (2005). Effect of an energyrestricted, highprotein, low-fat diet relative to a conventional high carbohydrate, low-fat diet on weight loss, body composition, nutritional status, and markers of cardiovascular health in obese women. Journal of the American Dietetic Association, 81(6), 1298-306. doi: 10.1093/ ajen/81.6.1298.

Noviana, A., Dieny, F., Rustanti, N., Anjani, G., \& Afifah, D.N. (2018). Antimicrobial activity of tempeh gembus hydrolyzate. IOP Conferences Series: Earth and Environmental Science, 116, 012044. doi: 10.1088/17551315/116/1/012044.

Oboh, G., \& Elusiyan, C.A. (2007). Changes in the Nutrient and Anti Nutrient of Micro Fungi Fermented Cassava Flour Produced from Low and Medium Cyanide Variety of Cassava Tubers. African Journal of Biotechnology, 6(18), 21502157. doi : 10.5897/AJB2007.000-2336.

Onweluzo, J.C., \& Nwabugwu, C.C. (2009). Fermentation of millet (Pennisetum americanum) and pigeon pea (Cajanus cajan) seeds for flour production; effects on composition and selected functional properties. Pakistan Journal of Nutrition, 8,737-744. doi: 10.3923/ pjn.2009.737.744

Palupi, N.S., Zakaria, F.R., \& Prangdimurti, E. (2007). Effect of Processing on Food Nutrition Value. Bogor: Fateta IPB.

Park, Y.W., \& Bell, L.N. (2004). Determination of Moisture and Ash Contents of Foods. Handbook of Food Analysis, Second Edition-3, 55-82. doi: 10.1201/b11081-5.

Partina, R.S., Maulana, I.T., \& Dasuki, U.A. (2015). Effect of Different Drying Processes on the Fatty Content of Tilapia Fish (Oreochromis mossambicus peters). Bandung: Universitas Islam Bandung.

Permatasari, P.K. (2012). Nugget Tempe with Mujair Fish Substitution as an Alternative Food of Source Protein, Fiber, and Low Fat. [Undergraduate Thesis]. Semarang: Diponegoro University.

Petracci, M., Bianchi, M., Mudalal, S., \& Cavani, C. (2013). Functional ingredients for poultry meat products. Trends Food Sci. Technol, 33(1), 27-39.

Puwastien, P., Siong, T.E., \& Aguinaldo, A. (2011). Asean manual of nutrient analysis, Regional Centre of ASEAN Network of Food Data System, Institute of Nutrition, Mahidol University, Thailand.

Ratu, A.D.S. (2009). Effect of Temperature and Frying Time on the Formation of Trans Fatty Acids. Makara Sains, 13(1), 23-28.

Saputra, D. (2014). Determination of Protein Digestibility in Vitro of Pomfret (Colossoma macropomum) at Different Harvest Ages. Food Technology, 5(2), 1127-1133.

Sudarmadji, S., B, Haryono., \& Suhardi. (2007). Food and Agriculture Material Analysis. Yogyakarta: Liberty.

Sulchan, M., \& Nur, E. (2007). Nutritional Value and Amino Acid Composition of Tempe Gembus and Its Effect on Growth of Rats. Majalah Kedokteran Indonesia 57(3), 80-85.

Sulthoniyah, S.T.M., Sulistyawati, T.W., \& Suprayitno, Eddy.. (2013). Effect of Steaming Temperature on the Nutrient and Organoleptic Content of Shredded Cork Fish. THP Student Journal, 1(1), 39.

Sumiati. T. (2008). Effect of processing on the digestibility of tilapia fish protein (Tilapia 
mossambica) [Undergraduate Thesis]. Bogor: IPB University.

Suwoyo, H. (2006). Chicken Nugget Vegetable Product Development of Skinless Boneless Breast based by adding Carrot Flakes in PT. Charoen Pokphand Indonesia Chicken Processing Plant, Cikande-Serang. [Undergraduate Thesis]. Bogor: IPB University.

Thed, S.T., \& Philliphs, R.D. (1995). Changes of dietary fiber and starch composition of processed potato products during domestic cooking. Food Chemistry, 52, 301-304.

Uttara, S., \& Kochhar, A. (2011). Metabolic Syndrome and its Relation with Dietary Fibers. Proceeding of the Indian National Science Academy, 77(1), 69-77.

Van, Boekel M.A.J.S. (2006). Formation of flavour compounds in the Maillard reaction. Biotechnology Advances, 24(2), 230-233. doi:10.1016/j.biotechadv.2005.11.004.

Ventura, E.E., Davis, J.N., Alexander, K.E., Shaibi, G.Q., Lee, W., Byrd-Williams, C.E., Toledo-Corral, C.M., Lane, C.J., Kelly, L.A.,Weigensberg, M.J., \& Goran, M.I. (2008). Dietary intake and the metabolic syndrome in overweight Latino children. Journal of the American Dietetic Association, 108(8), 13551359. doi: $10.1016 /$ j.jada.2008.05.006.

Winarno, F.G. (2008). Food and Nutrition Chemistry. Jakarta: Gramedia Pustaka Utama.

Wong, K.H., Aziz, S.A., \& Mohamed, S. (2008). Sensory aroma from Maillard reaction of individual and combinations of amino acids with glucose in acidic conditions. International Journal of Food Science \& Technology, 43(9), 151-1519. doi: 10.1111/j.13652621.2006.01445.x

Yuanita, I., \& Silitonga, L. (2014). Chemical Properties and Palatability of Chicken Nuggets Using Different Types and Concentrations of Filler Materials. Jurnal Ilmu Hewani Tropika, $3(1), 3,1-5$.

Yustiana, I. (2011). Utilization of Soybean Processing Waste in Rengginang Manufacturing. Balai Pengkajian Teknologi Pertanian Jawa Timur.

Zarnowski, R., \& Suzuki, Y. (2004). Expedient soxhlet extraction of resorcinolic lipids from wheat grains. Journal of Food Composition and Anallysis, 17(5), 649-663. doi: 10.1016/j. jfca.2003.09.007. 